\title{
SUPERSONIC PLASMA GAS AIR SPRAYING OF CERMET COATINGS OF THE (Ti, Cr)C-NiCr SYSTEM
}

\author{
Yu.S. BORISOV, A.L. BORISOVA, M.V. KOLOMYTSEV and O.P. MASYUCHOK \\ E.O. Paton Electric Welding Institute, NASU \\ 11 Bozhenko Str., 03680, Kiev, Ukraine. E-mail: office@paton.kiev.ua
}

\begin{abstract}
Effect of plasma gas air spraying (PGAS) factors (plasmatron power, consumption of plasma gas, spraying distance, anode diameter) of mechanical mixture from double titanium-chromium carbide and nichrome powders on characteristics of produced coatings (structure, microhardness, porosity, chipping resistance) was investigated. Program of experiments was composed using mathematical planning method. Regression equations, determining quantitative dependence of values of average and maximum microhardness, stability of microhardness indices and level of chipping on spraying process factors, were received based on data processing results. Indices of heat content in plasma jet and duration of powder particle passing through plasma jet were used for analysis of the results. It is determined that mode of plasma jet outflow and value of its heat content have the largest effect on structure and properties of produced coatings. Using $10 \mathrm{~mm}$ diameter anode, providing supersonic jet outflow mode at $5.6 \mathrm{~kW} \cdot \mathrm{h} / \mathrm{m}^{3}$ heat content index, for PGAS of coatings from mechanical mixture of titanium-chromium carbide and nichrome powders (3:1) promotes for formation of dense coatings (porosity $<1 \%$ ) with cermet structure (titanium-chromium carbide and nichrome). Such coatings have average microhardness $12.6 \mathrm{GPa}$ that 1.5 times exceeds microhardness of thermal coatings from mechanical mixture of chromium carbide and nichrome powders (8.6 GPa). 20 Ref., 6 Tables, 2 Figures.
\end{abstract}

$\boldsymbol{K} \boldsymbol{e} \boldsymbol{y} \boldsymbol{w} \boldsymbol{O} \boldsymbol{r} \boldsymbol{s}:$ cermets, double titanium-chromium carbide, supersonic plasma gas air spraying, coating properties, microhardness, experiment planning

The most wide-spread class of coatings, protecting surface of the parts from different types of wear [1-3], is the thermal coatings with cermet structure, consisting from metallic matrix, mainly based on nickel, cobalt or iron alloys with strengthening phase principally of tungsten, chromium or titanium carbides. In recent times they receive specific attention due to possibility of their application as alternative to solid chromium coatings. This allows for solving one the current tasks of environment protection [4-6].

WC-Co and $\mathrm{Cr}_{3} \mathrm{C}_{2}-\mathrm{NiCr}[3,6,7]$ cermet systems received the widest practical application. The leading world companies Starck (Germany), Sulzer (USA) and Praxair (USA) had developed compositions and mastered series of technologies for manufacture of powders of these materials, being special in their properties for application at plasma, detonation and high-velocity oxy-fuel spraying units [8-10]. These materials are delivered in form of mechanical mixtures of carbide powders and matrix alloy or conglomerate powders of cermet components, preliminary subjected to sintering-grinding of mechanical mixture or its conglomeration-sintering. Properties of produced coatings depend to significant extent on powder production method [11].
Compositions of $\mathrm{WC}-$ Co cermets for thermal spraying differ on cobalt content (12-17 wt.\%), and additional chromium alloying ( $4-8$ wt.\%) is used for increase of corrosion resistance. Microhardness of produced coatings depends on cobalt content and makes $H V 0.3-1200$ at $12 \%$ Co and $H V 0.3-900-1000$ at $17 \%$ Co [8].

Content of $\mathrm{NiCr}$ in compositions of cermets for thermal spraying of $\mathrm{Cr}_{3} \mathrm{C}_{2}-\mathrm{NiCr}$ system lies in $15-25 \mathrm{wt} . \%$ range, and average microhardness significantly varies depending on $\mathrm{NiCr}$ amount ( $H V$ V0.3-1035 for $\mathrm{Cr}_{3} \mathrm{C}_{2}-15 \% \mathrm{NiCr} ; H V 0.3-865$ for $\mathrm{Cr}_{3} \mathrm{C}_{2}-25 \% \mathrm{NiCr}$ ), as well as method of powder production. It rises in the case of $\mathrm{Cr}_{3} \mathrm{C}_{2}-25 \%$ $\mathrm{NiCr}$ to $H V 0.3-1100$ at transfer from application of mechanical mixture of powders to powder produced by method of preliminary agglomeration of mixture of fine powder components with further sintering [11]. A reason of such change is more uniform distribution of components and presence of product of carbide and alloy interaction during sintering.

Important service property of studied cermet coatings, determining area of their practical application, is the maximum temperature of their operation. In air it makes $480-500{ }^{\circ} \mathrm{C}$ for $\mathrm{WC}-\mathrm{Co}$ and $870-900{ }^{\circ} \mathrm{C}$ for $\mathrm{Cr}_{3} \mathrm{C}_{2}-\mathrm{NiCr}$ cermets [8-10] according to passport data, represented by companies-manufacturers of special powders for thermal spraying. However, safe protection of coat- 
Table 1. Characteristics of powder-components of $(\mathrm{Ti}, \mathrm{Cr}) \mathrm{C}-$ $\mathrm{NiCr}$ mechanical mixture

\begin{tabular}{||l|c|c|c|c||}
\hline \multicolumn{1}{|c|}{ Material } & $\begin{array}{c}\text { Composition, } \\
\text { wt.\% }\end{array}$ & $\begin{array}{c}\text { Melting } \\
\text { tempera- } \\
\text { ture, }{ }^{\circ} \mathrm{C}\end{array}$ & $\begin{array}{c}\text { Density, } \\
\mathrm{g} / \mathrm{cm}^{3}\end{array}$ & $\begin{array}{c}\text { Particle } \\
\text { size, } \mu \mathrm{m}\end{array}$ \\
\hline $\begin{array}{l}\text { Double tita- } \\
\text { nium-chromium } \\
\text { carbide }\end{array}$ & $\begin{array}{c}\mathrm{TiC}-70, \\
\mathrm{Cr}_{3} \mathrm{C}_{2}-30\end{array}$ & $\sim 2750$ & 5.35 & $15-40$ \\
\hline Nichrome & $\begin{array}{c}\mathrm{Ni}-80, \\
\mathrm{Cr}-20\end{array}$ & 1400 & 8.40 & $40-63$ \\
\hline
\end{tabular}

ing from oxidation in the case of $\mathrm{Cr}_{3} \mathrm{C}_{2}-\mathrm{NiCr}$ cermet is provided due to formation of dense $\mathrm{Cr}_{3} \mathrm{C}_{2}$ film on its surface that takes place in $600-$ $700{ }^{\circ} \mathrm{C}$ temperature area [12].

In this connection, development of thermal cermet coating, providing surface protection from wear at operating temperatures of $500-$ $700{ }^{\circ} \mathrm{C}$, is of current importance. Double titanium-chromium carbide can be referred to carbide materials with such property. It has high oxidation resistance at up to $1100{ }^{\circ} \mathrm{C}$, and at the same time exceeds titanium carbide ( $32 \mathrm{GPa}$ ) and chromium carbide (22.8 GPa) on microhardness value (up to $40 \mathrm{GPa}$ ) [13].

Experiments on deposition of cermet coatings, containing double titanium-chromium carbide ( $\mathrm{Ti}, \mathrm{Cr}) \mathrm{C}$ were based on application of composite powders $(\mathrm{Ti}, \mathrm{Cr}) \mathrm{C}$, clad by nickel [14-16] or nickel-molybdenum [17]. The coatings were produced by plasma spraying method using argonhydrogen mixture [14-17] as working gas as well as under conditions of plasma gas air spraying (PGAS) at subsonic and supersonic mode of plasma jet outflow [17].

The structure of plasma coatings, produced using $\mathrm{Ar} / \mathrm{H}_{2}$ plasma jet and $30-35 \mathrm{~kW}$ plasmatron power [17], consists of carbide phase of $H V$ 25-30 GPa microhardness, metallic phase with $H V 1.8 \mathrm{GPa}$ as well as phase having $H V 15^{-}$ $16 \mathrm{GPa}$ and, apparently, being a product of interaction of $(\mathrm{Ti}, \mathrm{Cr}) \mathrm{C}$ with shell metal of particles $(\mathrm{Ni})[14,15]$.

Analysis of phase and structure transformations in powders of pure and clad $(\mathrm{Ti}, \mathrm{Cr}) \mathrm{C}$, which take place under PGAS conditions, showed that supersonic mode provides for reduction of level of sprayed material oxidation and increase stability of clad shell on carbide core.

Table 2. Matrix of fractional factorial experiment $2^{3-1}$

\begin{tabular}{|c|c|c|}
\hline \hline Number of experiment & $X_{1}$ & $X_{2}$ \\
\hline 1 & + & + \\
\hline 2 & + & - \\
\hline 3 & - & + \\
\hline 4 & - & - \\
\hline
\end{tabular}

Examination of heat resistance of plasma coatings from $\mathrm{Ni}(\mathrm{Ti}, \mathrm{Cr}) \mathrm{C}$ composite powders with 30-35 wt.\% Ni showed that they have sufficiently high oxidation resistance at $800{ }^{\circ} \mathrm{C}$ in air $[15,18]$.

Aim of the present work lies in experiments on deposition of coatings from mechanical mixture of ( Ti, Cr)C and NiCr powders under conditions of supersonic PGAS for determination of effect of its main parameters on structure and properties of coatings being produced.

Materials and equipment. Mechanical mixture of powders of double titanium-chromium carbide with $7: 3$ proportion of $\mathrm{TiC}: \mathrm{Cr}_{3} \mathrm{C}_{2}$ and in 3:1 proportion of nichrome were used as spraying material. Table 1 gives the characteristics of $(\mathrm{Ti}, \mathrm{Cr}) \mathrm{C}$ and $\mathrm{NiCr}$.

Coating deposition was carried out on «KievS» machine for supersonic PGAS, developed together with Gas Institute and E.O. Paton Electric Welding Institute of NASU [19]. Air was applied as a plasma gas.

Experiment procedure. Method of mathematical planning of experiment was applied for development of research program. Plan of experiments on coating spraying was compiled using the blocks of matrix of fractional factorial experiment $2^{3-1}$ for different diameter size of anode nozzle $d_{\mathrm{a}}=10$ and $11 \mathrm{~mm}$ (Table 2 ). Fundamental difference in conditions of spraying process with 10 and $11 \mathrm{~mm}$ anode diameters lies in nature of plasma jet outflow.

In the first case $\left(d_{\mathrm{a}}=10 \mathrm{~mm}\right)$ it has supercritical nature, i.e. a jet is supersonic. In the second case $\left(d_{\mathrm{a}}=11 \mathrm{~mm}\right)$ it can lie in pre-critical as well as critical area depending on electric power and consumption of plasma gas, i.e. the jet should be considered subsonic. Plasmatron electric power $W, \mathrm{~kW}\left(X_{1}\right)$, consumption of plasma gas (air) $G, \mathrm{~m}^{3} / \mathrm{h}\left(X_{2}\right)$ and spraying distance $L, \mathrm{~mm}$ (Table 3 ) were taken as variables. Consumption of spray material $(6 \mathrm{~kg} / \mathrm{h})$ remained constant for all experiments.

Table 4 shows the working plan, composed in accordance with matrix of fractional factorial experiment planning.

Analysis of process of plasma spraying of coatings with cermet structure using mechanical mixtures of powders from carbides and alloy, which is metallic matrix of structure, in the case of their mutual feed in the jet requires consideration of series of fundamental peculiarities of such a process [20]:

- separation of traveling path of particles of carbide and metal and appearance of inhomogeneity of their concentration in jet volume are possible at the initial stage of the process during entering of gas- 
Table 3. Intervals of variation and values of factors of PGAS of coatings

\begin{tabular}{||l|c|c|c|}
\hline \multirow{2}{*}{ Variation parameters } & \multicolumn{3}{|c|}{ Factors } \\
\cline { 2 - 4 } & $W, \mathrm{~kW}$ & $G, \mathrm{~m}^{3} / \mathrm{h}$ & $L, \mathrm{~mm}$ \\
\hline Upper level + & 90 & 24 & 200 \\
\hline Lower level - & 70 & 16 & 160 \\
\hline Base level 0 & 80 & 20 & 180 \\
\hline Variation interval & 10 & 4 & 20 \\
\hline
\end{tabular}

powder mixture in plasma jet at difference of density values and component part size;

- difference in value of melting difficulty parameter of metal and carbide particle material $[1,2]$ and sizes of their particles results in inhomogeneity of their melting conditions at heating in plasma jet, which can be aggravated in the case of mentioned above separation of particles of cermet components in jet volume;

- one of the main requirements to selection of parameters of plasma spraying of carbide material coatings is minimizing of carbon loss, taking place at movement of particles in the jet oxygencontaining zones, which depend on level of carbide particle overheating above the melting temperature, spraying distance, speed and path of powder particle flying.

As long as providing wear resistance is one of the main tasks of technology of plasma spraying of carbide-containing cermet coatings, then the following was used as response functions in experiment plan:

- $H_{\mu}^{\mathrm{av}}$ - average microhardness of coating $(\mathrm{GPa})$ as characteristic of its structure and index of its possible wear resistance;

- $H_{\mathrm{u}}^{\max }-$ maximum microhardness of coating (GPa), characterizing the level of preservation of carbide microhardness, i.e. value of carbon loss;

- $\Delta X / H_{\mu}^{\mathrm{av}}-$ relationship of confidence interval to average coating microhardness, reflecting the level of structure homogeneity of produced coating;

- $B$ - level of coating chipping as index of coating cohesion strength related with particle heating inhomogeneity;

- phase composition and coating porosity.

Two complexes of spraying process parameters were developed for analysis of relationship of obtained results with conditions of spraying process, in particular, characteristics of plasma jet and time of staying in jet volume of particle of spray material effecting heat transfer development as well as level of particle interaction with ambient atmosphere:

- $K_{\mathrm{h}}=W / G, \mathrm{~kW} \cdot \mathrm{h} / \mathrm{m}^{3}-$ index of heat content of plasma jet, received by it during passing through arc discharge;
Table 4. Plan of experimental work on PGAS of $75(\mathrm{Ti}, \mathrm{Cr}) \mathrm{C}+$ $+25 \mathrm{NiCr}$ powder

\begin{tabular}{||c|c|c|c|}
\hline $\begin{array}{c}\text { Number of } \\
\text { experiment }\end{array}$ & $W, \mathrm{~kW}$ & $G, \mathrm{~m}^{3} / \mathrm{h}$ & $L, \mathrm{~mm}$ \\
\hline \multicolumn{4}{|c|}{$d_{\mathrm{a}}=10 \mathrm{~mm}$} \\
\hline $1 / 1$ & 90 & 24 & 200 \\
\hline $2 / 1$ & 90 & 16 & 160 \\
\hline $3 / 1$ & 70 & 24 & 160 \\
\hline $4 / 1$ & 70 & 16 & 200 \\
\hline \multicolumn{4}{|c|}{$d_{\mathrm{a}}=11 \mathrm{~mm}$} \\
\hline $1 / 2$ & 90 & 24 & 200 \\
\hline $2 / 2$ & 90 & 16 & 160 \\
\hline $3 / 2$ & 70 & 24 & 160 \\
\hline $4 / 2$ & 70 & 16 & 200 \\
\hline
\end{tabular}

- $K_{\tau}=2.82 L d_{\mathrm{a}}^{2} / G, \mathrm{~s}-$ index of duration of process of powder particle movement in jet volume up to the moment of collision to base surface.

The coatings were deposited on surface of steel samples, preliminary subjected to jet-abrasive machining using corundum powder. Consumption of transporting gas was selected in such a way that flying path of particles of $(\mathrm{Ti}, \mathrm{Cr}) \mathrm{C}$ and $\mathrm{NiCr}$ powders was located in plasma jet axial zone.

Methods of metallography («Neophot-32»), $\mathrm{X}$-ray-phase analysis (DRON-3M, $\mathrm{Cu} K_{\alpha}$ with nickel filter) and microhardness gage PMT-3 were use for examination of coating structure and properties. Coating porosity was determined in dark background of section image and amount of chipping was measured using ImagePro program.

Results of experiment and discussion. Table 5 shows the results of examination of structure and properties of the coatings, produced during performance of experiment plan in accordance with Table 4. Figure 1 represents microstructure of coatings, deposited using the modes corresponding to working plan. Coating thickness lied in $150-250 \mu \mathrm{m}$ range.

Microstructures of coatings, presented in $\mathrm{Fi}$ gure 1 , can be divided on two groups:

- 2/1, 4/1, 1/2 and $2 / 2$, which differ by high density (porosity <1\%) with low chipping level $(5-10 \%)$ and absence of inclusions of unmelted particles at the largest thickness of produced layer (to $250 \mu \mathrm{m}$ );

- $1 / 1,3 / 1,3 / 2$, and $4 / 2$, where porosity is increased to $3 \%$, the inclusions of unmelted particles and increased chipping level (to 13-15\%) are observed, and layer thickness makes 100-150 $\mu \mathrm{m}$.

Presence of such microstructure peculiarities can be explained by difference in conditions of their deposition and, first of all, different value of $K_{\mathrm{h}}$ index, characterizing plasma jet heat content. As for the first group it makes 4.4-5.6, and that for the second group is $2.9-3.75 \mathrm{~kW} \cdot \mathrm{h} / \mathrm{m}^{3}$. 
Table 5. Characteristics of structure and properties of PGAS $(\mathrm{Ti}, \mathrm{Cr}) \mathrm{C}-\mathrm{NiCr}$ coatings produced in accordance with experiment plan (acc. to Table 4).

\begin{tabular}{|c|c|c|c|c|c|c|c|c|c|c|}
\hline \multirow[t]{2}{*}{$d_{\mathrm{a}}, \mathrm{mm}$} & \multirow{2}{*}{$\begin{array}{l}\text { Number of } \\
\text { experiment }\end{array}$} & \multicolumn{2}{|c|}{$\begin{array}{l}\text { Microhardness } \\
H V 0.05, \mathrm{GPa}\end{array}$} & \multirow{2}{*}{$\Delta X / H_{\mu}^{\mathrm{av}}$} & \multirow{2}{*}{$\begin{array}{c}\text { Chipping } \\
B, \%\end{array}$} & \multirow[t]{2}{*}{ Phase composition } & \multirow[t]{2}{*}{$\begin{array}{c}\text { Porosity, } \\
\%\end{array}$} & \multirow[t]{2}{*}{$\begin{array}{c}\text { Structure } \\
\text { peculiarity }\end{array}$} & \multirow{2}{*}{$K_{\mathrm{h}}, \mathrm{kW} \cdot \mathrm{h} / \mathrm{m}^{3}$} & \multirow{2}{*}{$K_{\tau} \cdot 10^{-3}, \mathrm{~s}$} \\
\hline & & $H_{\mu}^{\mathrm{av}}$ & $H_{\mu}^{\max }$ & & & & & & & \\
\hline \multirow[t]{4}{*}{10} & $1 / 1$ & 5.70 & 8.86 & 0.2 & 12 & $\begin{array}{c}\mathrm{NiCr}, \\
(\mathrm{Ti}, \mathrm{Cr}) \mathrm{C}, \\
\mathrm{Ti}_{2} \mathrm{O}_{5}, \mathrm{CrTiO}_{3}\end{array}$ & $<3$ & $\begin{array}{l}\text { Unmelted } \\
\text { particles }\end{array}$ & 3.75 & 2.35 \\
\hline & $2 / 1$ & 12.60 & 19.14 & 0.208 & 5 & $\begin{array}{l}(\mathrm{Ti}, \mathrm{Cr}) \mathrm{C}, \mathrm{NiCr}, \\
\mathrm{CrTiO}_{3}, \mathrm{NiCrO}\end{array}$ & $<1$ & Same & 5.6 & 2.82 \\
\hline & $3 / 1$ & 3.36 & 6.43 & 0.214 & 15 & $\begin{array}{c}\mathrm{NiCr}, \\
(\mathrm{Ti}, \mathrm{Cr}) \mathrm{C} \\
\mathrm{Ti}_{2} \mathrm{O} 5, \mathrm{CrTiO}_{3}\end{array}$ & $<3$ & » & 2.9 & 1.88 \\
\hline & $4 / 1$ & 6.20 & 10.78 & 0.303 & 10 & $\begin{array}{c}(\mathrm{Ti}, \mathrm{Cr}) \mathrm{C}, \mathrm{NiCr}, \\
\mathrm{CrTiO}_{3}, \mathrm{NiCrO}\end{array}$ & $<1$ & $»$ & 4.4 & 3.70 \\
\hline \multirow[t]{4}{*}{11} & $1 / 2$ & 6.98 & 8.86 & 0.251 & 12 & $\begin{array}{c}\mathrm{NiCr},(\mathrm{Ti}, \mathrm{Cr}) \mathrm{C} \\
\mathrm{CrTiO}_{3}\end{array}$ & $<1$ & » & 3.75 & 2.84 \\
\hline & $2 / 2$ & 7.45 & 13.36 & 0.204 & 8 & $\begin{array}{c}\mathrm{NiCr},(\mathrm{Ti}, \mathrm{Cr}) \mathrm{C}, \\
\mathrm{CrTiO}_{3}, \mathrm{Cr}_{23} \mathrm{C}_{6}\end{array}$ & $<1$ & $\gg$ & 5.6 & 3.41 \\
\hline & $3 / 2$ & 6 & 10.23 & 0.218 & 10 & $\begin{array}{l}\mathrm{NiCr},(\mathrm{Ti}, \mathrm{Cr}) \mathrm{C} \\
\mathrm{CrTiO}_{2}, \mathrm{TiO}\end{array}$ & $<3$ & $\begin{array}{c}\text { Coarse } \\
\text { unmelted } \\
\text { particles }\end{array}$ & 2.9 & 2.27 \\
\hline & $4 / 2$ & 5.30 & 10.23 & 0.166 & 13 & $\begin{array}{c}\mathrm{NiCr},(\mathrm{Ti}, \mathrm{Cr}) \mathrm{C} \\
\mathrm{CrTiO}_{3}, \mathrm{NiCrO}\end{array}$ & $<3$ & Same & 4.4 & 4.48 \\
\hline
\end{tabular}

This in combination with the first group with increased index of heating time $\left((2.82-3.7) \cdot 10^{-3} \mathrm{~s}\right)$ provides for efficient particle heating and formation of dense coating structure with increased cohesion strength.

Similar conclusion was made during analysis of indices of coating microhardness, where coatings from the first group have higher values of average (6.2-12.6) and maximum microhardness $(10.78-19.14 \mathrm{GPa})$ then coatings of the second group (3.36-6.98 and 6.43-10.23 GPa, respectively). Data on phase composition of coatings can explain these results.

Since $(\mathrm{Ti}, \mathrm{Cr}) \mathrm{C}-\mathrm{NiCr}$ coating is cermet on its structure, then it consists of phase of $\mathrm{NiCr}$ metallic binder and $(\mathrm{Ti}, \mathrm{Cr}) \mathrm{C}$ carbide phase, varying by significantly different hardness. In this connection, obtained data on measurement of average microhardness reflect a relationship of these phases in coating volume. $(\mathrm{Ti}, \mathrm{Cr}) \mathrm{C}$ and $\mathrm{NiCr}$ volume fractions in accordance with their weight proportion 3:1 and material density (see Table 1) make 82 and $18 \%$, respectively, in initial sprayed material. Difference of component melting temperature in process of spraying firstly provokes for melting of $\mathrm{NiCr}$, and participation of $(\mathrm{Ti}, \mathrm{Cr}) \mathrm{C}$ in coating formation depends on development of heat exchange processes. According to condition mentioned above, they are more favorable for carbide melting in experiments $2 / 1$ and $4 / 1$, that is verified by phase composition of these coatings (see Table 5). Conditions of experiments $2 / 1$ and $2 / 2$ are virtually the same on $K_{\mathrm{h}}$ and $K_{\tau}$ indices, however, composition and microhardness are different. Leading phase is $\mathrm{NiCr}$ in the case of $2 / 2$. This can be related with deviation of $(\mathrm{Ti}, \mathrm{Cr}) \mathrm{C}$ particle path to colder zone of plasma jet at transfer from supersonic to subsonic mode of jet outflow.

Regression equations were composed for determination of level of effect of different factors of spraying process modes on coating characteristics using data, obtained during performance of experiment plan according to Tables 4 and 5 .

In use of $10 \mathrm{~mm}$ diameter anode:

$$
\begin{gathered}
H_{\mu}^{\mathrm{av}}=7.04+0.021 W-0.024 G-0.011 L ; \\
H_{\mu}^{\max }=11.3+0.027 W-0.037 G-0.015 L ; \\
\Delta X / H_{\mu}^{\mathrm{av}}=0.213-0.014 W-0.0145 G+0.008 L ; \\
B=7-0.2 W+0.75 G+0.025 L .
\end{gathered}
$$

In use of $11 \mathrm{~mm}$ diameter anode:

$$
\begin{gathered}
H_{\mu}^{\mathrm{av}}=6.4+0.008 W+0.001 G-0.003 L ; \\
H_{\mu}^{\mathrm{max}}=10.7+0.011 W-0.004 G-0.011 L ; \\
\Delta X / H_{\mu}^{\mathrm{av}}=0.182-0.0083 W-0.0047 G+0.0069 L ; \\
B=9.5-0.15 W+0.25 G+0.05 L .
\end{gathered}
$$

Data of given above regression equations were used for plotting the diagrams of trends, reflecting intensity of effect of separate process factors on coating characteristics (Figure 2). 

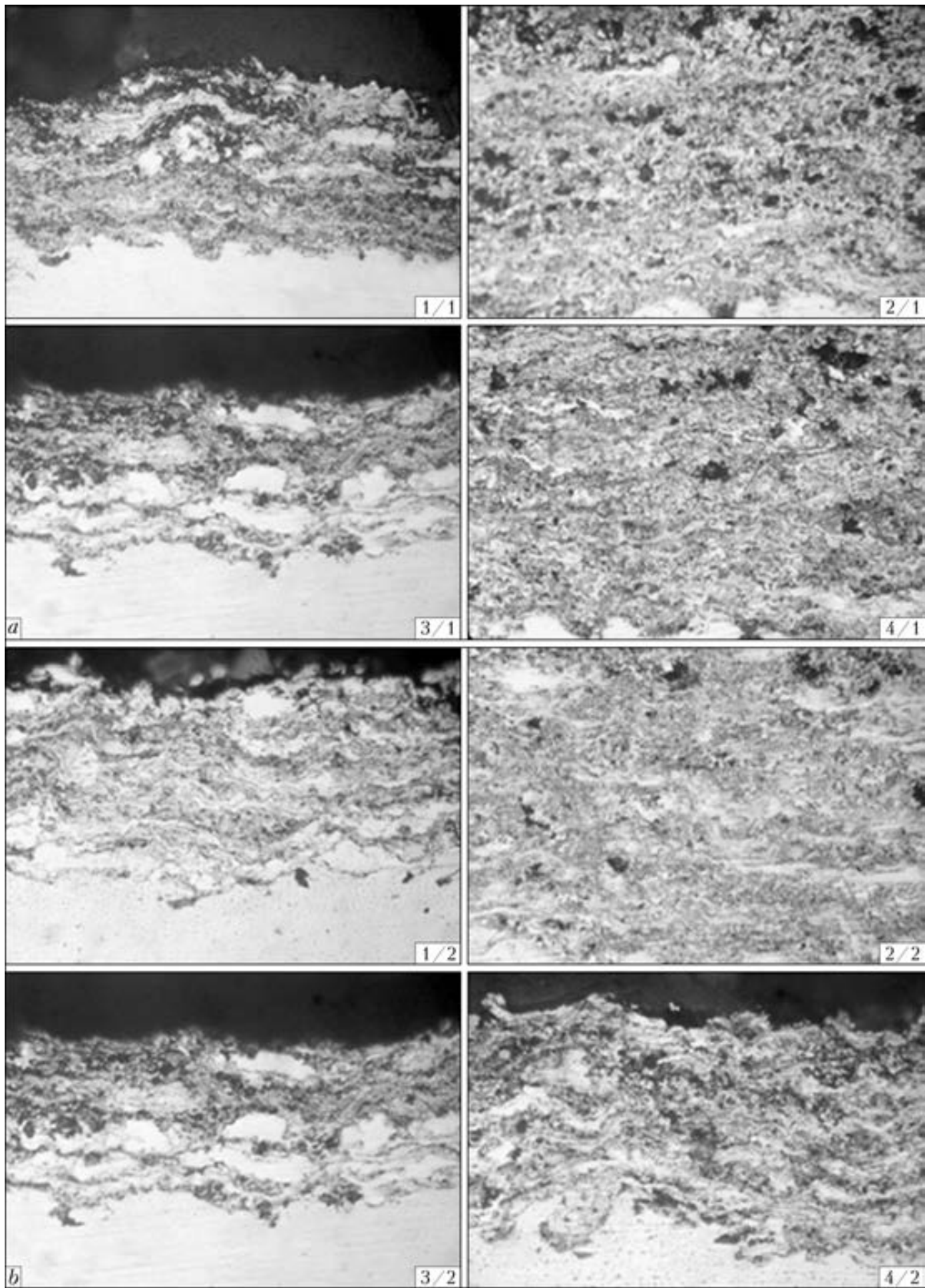

Figure 1. Microstructure $(\times 400)$ of $(\mathrm{Ti}, \mathrm{Cr}) \mathrm{C}-\mathrm{NiCr}$ coatings PGA-sprayed using modes acc. to Table 4: $a-$ anode diameter $10 \mathrm{~mm} ; b-11 \mathrm{~mm}$

Table 6 gives the correlation of nature and intensity of effect of different factors on properties of produced coatings (in selected experiment area), performed based on trend indices (see Figure 2).

It follows from Table 6 that trends of $d_{\mathrm{a}}=10$ and $11 \mathrm{~mm}$ are unidirectional for $W$ and $L$ factors. Increase of $W$ results in increase of $H_{\mu}^{\mathrm{av}}$ and $H_{\mu}^{\max }$, as well as reduction of $\Delta X / H_{\mu}^{\text {av }}$ and $B$, and inverse effect is observed in rise of $F$ factor. In whole it can be considered as relationship of quality of $(\mathrm{Ti}, \mathrm{Cr}) \mathrm{C}-\mathrm{NiCr}$ coating by indices of its hardness and cohesion strength with condition of particle heating, caused by plasma jet temperature. The difference lies in intensity of effect of these factors at different mode of plasma jet outflow. Level of change of coating properties at increase of plasmatron power and reduction 
Table 6. Character of effect of PGAS factors on properties of $(\mathrm{Ti}, \mathrm{Cr}) \mathrm{C}-\mathrm{NiCr}$ coating

\begin{tabular}{||c|c|c|c|c|c|c||}
\hline \multirow{3}{*}{ Properties } & \multicolumn{6}{|c||}{ PGAS factors at $d_{\mathrm{a}}, \mathrm{mm}$} \\
\cline { 2 - 8 } & \multicolumn{2}{|c|}{$W$} & \multicolumn{2}{|c|}{$G$} & \multicolumn{2}{|c||}{$L$} \\
\cline { 2 - 8 } & 10 & 11 & 10 & 11 & 10 & 11 \\
\hline$H_{\mu}^{\mathrm{av}}$ & $\uparrow \uparrow$ & $\uparrow$ & $\downarrow$ & $\sim$ & $\downarrow \downarrow$ & $\downarrow$ \\
\hline$H_{\mu}^{\max }$ & $\uparrow \uparrow$ & $\uparrow$ & $\downarrow$ & $\sim$ & $\downarrow \downarrow$ & $\downarrow$ \\
\hline$\Delta X / H_{\mu}^{\mathrm{av}}$ & $\downarrow \downarrow$ & $\downarrow$ & $\downarrow$ & $\sim$ & $\uparrow \uparrow$ & $\uparrow \uparrow$ \\
\hline$B$ & $\downarrow \downarrow$ & $\downarrow$ & $\uparrow$ & $\sim$ & $\sim$ & $\uparrow$ \\
\hline
\end{tabular}

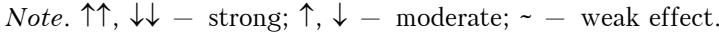

of spraying distance is more significant in the case of supersonic mode.

Difference between effect of spraying factors on properties under conditions of subsonic and
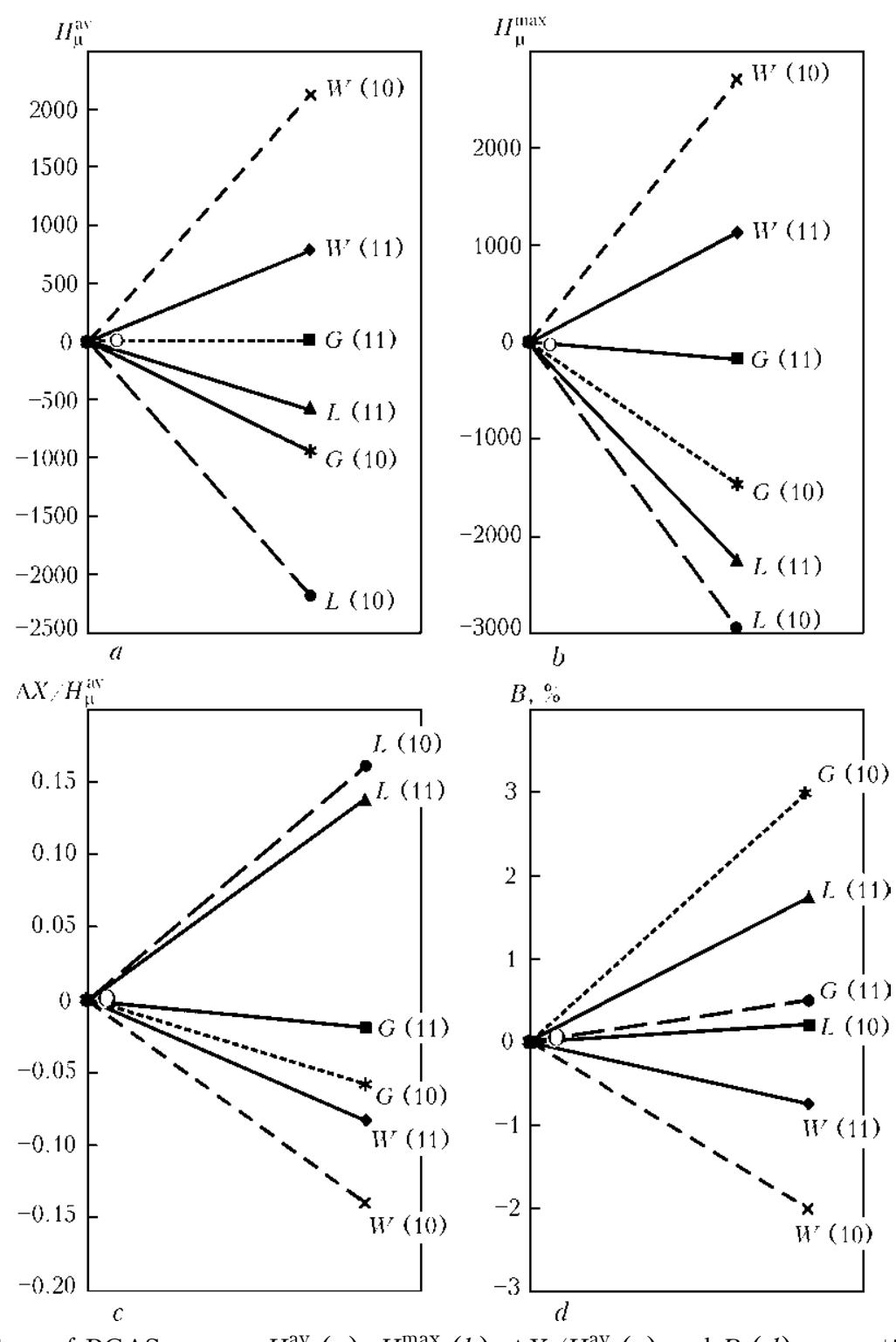

Figure 2. Effect of factors of PGAS process $H_{\mu}^{\mathrm{av}}(a), H_{\mu}^{\max }(b), \Delta X / H_{\mu}^{\mathrm{av}}(c)$ and $B(d)$ on coating characteristics; (10) and (11) - data of experiments carried at $d_{\mathrm{a}}=10$ and $11 \mathrm{~mm}$, respectively

supersonic modes is observed for plasma gas consumption $G$. If tendency to some deterioration of coating quality on microhardness as well as chipping level is found in the first case at increase of plasma gas consumption, then this effect is considerably insignificant in the second case.

Formation of coatings under PGAS conditions is certainly related with conditions of heating of cermet particles, which are described to significant extent by $K_{\mathrm{h}}$ and $K_{\tau}$ values. The values of coating characteristics are matched in Table 5 with value of these indices for each of eight experiment conditions. It follows from data of Table 5 that change of $K_{\mathrm{h}}$ value from 2.9 to $5.6 \mathrm{~kW} \cdot \mathrm{h} / \mathrm{m}^{3}$ under conditions of supersonic jet application is inseparably associated with phase composition of coatings, exceed of microhardness indices $\left(H_{\mu}^{\mathrm{av}}, H_{\mu}^{\max }\right)$ and reduction of level of its chipping and porosity. $K_{\mathrm{h}}=5.6 \mathrm{~kW} \cdot \mathrm{h} / \mathrm{m}^{3}$ and

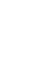


$K_{\tau}=2.82 \cdot 10^{-3}$ s provide for formation of coating with prevailing $(\mathrm{Ti}, \mathrm{Cr}) \mathrm{C}$ content in the structure, that promotes for maximum indices of average $\left(H_{\mu}^{\mathrm{av}}=12.60 \mathrm{GPa}\right)$ and maximum $\left(H_{\mu}^{\max }=\right.$ $=19.14 \mathrm{GPa})$ microhardness at minimum porosity $(<1 \%)$ and chipping level $(5 \%)$. This can be explained by heating of particles in plasma jet with high heat content at increased duration of heating time. Obtained microhardness of cermet coating $(\mathrm{Ti}, \mathrm{Cr}) \mathrm{C}-\mathrm{NiCr}$, produced from mechanical mixture of powders in 3:1 proportion by means of supersonic PGAS, is 1.5 times higher than microhardness of $\mathrm{Cr}_{3} \mathrm{C}_{2}-\mathrm{NiCr}$ coating from similar mechanical mixture of components, sprayed by HVOF method (8.6 GPa) [12].

Effect of $K_{\mathrm{h}}$ index is weaker in the case of subsonic mode of plasma jet outflow, however, maximum values of coating characteristics ( 7.45 and $13.36 \mathrm{GPa}$, respectively) are also achieved at its $5.6 \mathrm{~kW} \cdot \mathrm{h} / \mathrm{m}^{3}$ value, but structure mainly includes $\mathrm{NiCr}$ phase.

\section{Conclusions}

1. Results of complex of experiments, carried using mathematical planning method, were used as a basis for performance of analysis of effect of plasma jet outflow mode (subsonic and supersonic) and parameters of plasma gas air spraying (plasmatron electric power, consumption of plasma gas and spraying distance) of mechanical mixture of $(\mathrm{Ti}, \mathrm{Cr}) \mathrm{C}-\mathrm{NiCr}$ powders on structure and properties of produced coatings (microstructure, phase composition, microhardness, porosity, chipping resistance).

2. Analysis of received regression equations, reflecting quantitative relationship of value of coating characteristics with values of PGAS parameters, showed that plasmatron power and spraying distance have the largest effect on $(\mathrm{Ti}$, $\mathrm{Cr}) \mathrm{C}-\mathrm{NiCr}$ microhardness, moreover, the level of this effect is significantly more under conditions of spraying by supersonic jet.

3 . Indices of heat content $K_{\mathrm{h}}$ in plasma jet and relative duration of process of particle staying in the jet $K_{\tau}$ were proposed for analysis of conditions of spraying process. Change of $K_{\mathrm{h}}$ from 2.9 to $5.6 \mathrm{~kW} \cdot \mathrm{h} / \mathrm{m}^{3}$ results in increase of microhardness and porosity of the coatings, rise of $(\mathrm{Ti}, \mathrm{Cr}) \mathrm{C}$ content in phase structure and reduction of chipping level under supersonic mode of spraying.

4. The best indices of $(\mathrm{Ti}, \mathrm{Cr}) \mathrm{C}-\mathrm{NiCr}$ coating are received at plasmatron power $90 \mathrm{~kW}$, $24 \mathrm{~m}^{3} / \mathrm{h}$ consumption of plasma gas and $200 \mathrm{~mm}$ spraying distance. In this case, average micro- hardness of the coating makes $H V 0.0512 .6 \mathrm{GPa}$, maximum one is $19.14 \mathrm{GPa}$, porosity $<1 \%$ and chipping level makes $5 \%$ at prevailing $(\mathrm{Ti}, \mathrm{Cr}) \mathrm{C}$ phase in the structure.

1. Borisov, Yu.S., Borisova, A.L. (1986) Plasma powder coatings. Kiev: Tekhnika.

2. Borisov, Yu.S., Kharlamov, Yu.A., Sidorenko, S.L. et al. (1987) Thermal coatings from powder materials: Refer. Book. Kiev: Naukova Dumka.

3. Toma, D., Brandtt, W., Marginean, G. (2001) Wear and corrosion of thermoalloy sprayed cermet coatings. Surface and Coatings Technology, 138, 149-158.

4. Espallargas, N., Berget, J., Guilemany, J.M. et al. (2008) $\mathrm{Cr}_{3} \mathrm{C}_{2}-\mathrm{NiCr}$ and $\mathrm{WC}-\mathrm{Ni}$ spray coatings as alternatives to hard chromium for erosion-corrosion resistance. Ibid., 202, 1405-1417.

5. Fedrizzi, L., Rossi, S., Cristel, R. et al. (2004) Corrosion and wear behavior of HVOF cermet coatings used to replace hard chromium. Electrochimica Acta, 49, 2803-2814

6. Guilemany, J.M., Espallargas, N., Suegama, P.H. et al. (2006) Comparative study of $\mathrm{Cr}_{3} \mathrm{C}_{2}-\mathrm{NiCr}$ coatings obtained by HVOF and hard chromium coatings. Corrosion Sci., 48, 2998-3013.

7. Sahoo, P., Raghuraman, R. (1993) High temperature chromium carbides reinforced metal matrix composite coatings for turbomachinery application. In: Proc. of Thermal Spray Conf. (Aachen, Germany, 1993), 296-300.

8. Takeuchi, J., Nakahira, A. (1993) $\mathrm{Cr}_{3} \mathrm{C}_{2}-\mathrm{NiCr}$ cermet coatings using some HVOF, APS and UPS process. Ibid., 11-14.

9. Beczkowiak, J., Fisher, J., Schwier, Y. (1993) Cermet materials for HVOF processes. Ibid., 32-36.

10. (2000) Powder solutions catalog. In: Praxair Surface Technologies.

11. (2011) Thermal spray materials. In: Sulzer Metco Guide.

12. Keller, H., Pross, E., Schwier, G. (2000) Influence of the powder type on the structure and the properties of chromium carbide. In: H.C. Starck Nickel, Chromium Alloys. Specialist for Specialties.

13. Vojtovich, R.F., Pugach, E.A. (1973) Peculiarities of high temperature oxidation of carbides of VI group transition metals. Poroshk. Metallurgiya, 4, 59-64.

14. Gorbatov, I.N., Ilchenko, N.S., Terentiev, A.E. et al. (1991) Effect of cladding of double Ti-Cr carbide on properties of plasma coatings. Fiz.-Khimich. Obrab. Materialov, 3, 81-85.

15. Gorbatov, I.N., Shkiro, V.M., Terentiev, A.E. et al. (1991) Examination of properties of thermal coatings from composite powders of nickel-titanium and chromium carbide. Ibid., 4, 102-106.

16. Gorbatov, I.N., Panasyuk, A.D., Shvedova, L.K. et al. (1991) Thermal coatings on the base of titaniumchromium carbide. Zashch. Pokrytiya na Metallakh, Issue 25, 22-25.

17. Borisova, A.L., Chernets, A.I. (1993) Phase and structural transformations in powders of pure clad double titanium-chromium carbide in plasma jet. Problemy Spets. Elektrometallurgii, 3, 63-72.

18. Rajtses, V.B., Litvin, V.M., Rutberg, V.P. et al. (1986) Wear-resistant plasma coatings based on $\mathrm{Ti}-\mathrm{Cr}$ double carbide. Poroshk. Metallurgiya, 10, 46-47.

19. Borisov, Yu.S., Petrov, S.V. (1993) Application of supersonic jets in technology of thermal spraying. Avtomatich. Svarka, 1, 24-34.

20. Borisov, Yu.S., Fishman, S.L., Yushkov, V.I. et al. (1975) Cermet plasma coatings. In: Inorganic and organic-silicate coatings. Leningrad: Nauka.

Received 21.11.2014 